\title{
Hubungan Motivasi Belajar Instrinsik Terhadap Prestasi Belajar Biologi Kelas XI IPA di SMA Negeri 4 Tanjungpinang
}

\author{
Muhamad Kukuh Handoko ${ }^{1 *}$, Nevrita ${ }^{2}$, Nurul Asikin ${ }^{3,}$ \\ ${ }^{1}$ SMK Kesehatan Widya, Kota Tanjungpinang, Kepulauan Riau, Indonesia. \\ ${ }^{2,3}$ Program Studi Pendidikan Biologi/ Fakultas Keguruan dan Ilmu Pendidikan, Universitas Maritim Raja Ali Haji, Kota \\ Tanjungpinang, Indonesia \\ Pengiriman: 15 Juli 2019; Diterima: 15 Oktober 2019; Publikasi: Oktober 2019
}

\begin{abstract}
In this study, the researchers looked at the level of the relationship between intrinsic learning motivation towards biology learning achievement of students of class XI science in SMA 4 Tanjungpinang. In this study, researchers used a sample of research consisting of students and students from class XI IPA 1 to class XI IPA 5, amounting to 84 students. The data collection techniques in this study used two research instruments, namely questionnaire and question instruments. The questionnaire instrument was used to measure the value of intrinsic learning motivation while the test instrument was used to measure student learning achievement. Based on the results of the Pearson product moment test, the significance direction is 0.00 , meaning that there is a correlation between the above variables, then, the relationship between intrinsic learning motivation towards learning achievement produces a value of $0.50 \mathrm{which}$ is categorized into adequate correlation.
\end{abstract}

Keywords: Correlation Research, Learning Achievement, Intrinsic Learning Motivation

\begin{abstract}
ABSTRAK. Penelitian ini bertujuan untuk mengetahui tingkat hubungan antara motivasi belajar instrinsik terhadap prestasi belajar biologi siswa kelas XI IPA di SMA Negeri 4 Tanjungpinang. Dalam penelitian ini, peneliti menggunakan sampel penelitian yang terdiri dari siswa dan siswa dari kelas XI IPA 1 sampai kelas XI IPA 5 yang berjumlah 84 orang siswa. Adapun teknik pengumpulan data dalam penelitian ini menggunakan dua instrument penelitian yaitu instrument angket dan soal.Instrument angket digunakan untuk mengukur nilai motivasi belajar instrinsik sementara instrument tes digunakan untuk mengukur prestasi belajar siswa. Berdasarkan hasil analisis uji pearson product moment, arah signifikasinya bernilai 0,00 artinya terdapat korelasi antara variabel diatas, selanjutnya, tentang hubungan antara motivasi belajar instrinsik terhadap prestasi belajar menghasilkan nilai sebesar 0,50 yang dikategorikan ke dalalm korelasi sedang. Maka dapat diambil kesimpulan bahwa hipotesis diatas diterima.
\end{abstract}

Kata Kunci: Penelitian korelasi, Prestasi Belajar, Motivasi Belajar Instrinsik

*Penulis korespondensi:

Alamat surel : kukuhhandoko22@yahoo.com 


\section{PENDAHULUAN}

Pendidikan merupakan wahana yang penting dalam rangka menciptakan kader-kader bangsa sebagai generasi penerus bangsa yang berkualitas.Pendidikan nasional bertujuan untuk meningkatkan kualitas manusia Indonesia. Melalui pendidikan, manusia dibina dan

dikembangkan segala potensi-potensinya. Hal ini dilakukan dengan tujuan agar menjadikan anak didik itu sebagai manusia yang berkualitas, bertanggungjawab dan berakhlak mulia.

Belajar merupakan kegiatan yang berhubungan dengan mental dan psikis serta melibatkan fisik dalam kegiatannya dan terjadi secara terus-menerus.Belajar juga melibatkan pengetahuan dan pengalaman untuk membuat perubahan dalam hidup seseorang. Belajar juga memiliki arti sebagai sekumpulan perubahan tingkah laku berdasarkan pengalaman

yang telah didapat. Dalam proses belajar, terdapat salah satu komponen penting yaitu motivasi belajar, Menurut Sardiman (2010: 73) "motivasi adalah perubahan energi dalam diri (pribadi) seseorang yang ditandai dengan timbulnya perasaan dan reaksi untuk mencapai tujuan".

Selanjutnya berdasarkan sudut pandangnya, motivasi belajar dibagi atas dua yaitu motivasi belajar dibagi atas dua hal yaitu motivasi belajar instrinsik dan motivasi belajar ekstrinsik.Pertama, motivasi belajar instrinsik adalah daya dorong dalam belajar yang datangnya dari dalam diri siswa seperti keinginan, kemauan, niat dan lainnya.Pendapat ini didukung oleh pendapat ahli yaitu Menurut Sardiman (2012: 98) berpendapat bahwa "Motivasi instrinsik adalah hal dan keadaan yang berasal dari dalam diri siswa sendiri yang dapat mendorong melakukan tindakan belajar.kemudian kedua, motivasi belajar ekstrinsik adalah dorongan dalam belajar yang datangnya dari luar diri siswa seperti lingkungan sekitar, keluarga, teman, pujian, hukuman dan lainnya. Pendapat peneliti tentang motivasi belajar ekstrinsik ini didukung oleh teori yang disampaikan oleh ahli, Menurut Supandi (2011:
61) "Motivasi ekstrinsik adalah motivasi yang timbul manakala terdapat rangsangan dari luar individu". Menurut Thomas (2010: 39) "motivasi ekstrinsik adalah motivasi penggerak atau pendorong dari luar yang diberikan dari ketidakmampuan individu sendiri". Namun dalam jurnal ilmiah ini, peneliti hanya akan membahas tentang motivasi belajar instrinsik saja.

Berdasarkan penjelasan diatas, dapat diambil kesimpulan bahwa motivasi belajar merupakan salah satu komponen yang penting dalam proses pembelajaran siswa baik disekolah maupun diluar sekolah. Motivasi belajar memegang peranan penting didalamnya karena merupakan daya penggerak siswa dalam melakukan segala macam aktivitas belajar.oleh karena itu, motivasi belajar siswa harus senantiasa dijaga dan ditingkatkan. Motivasi yang bersumber dari dalam diri siswa disebut dengan motivasi belajar instrinsik.Motivasi instrinsik ini meliputi keinginan diri, kepuasaan, kebiasaan baik, kesadaran.

Dalam setiap proses pembelajaran yang dilalui oleh siswa, akhirnya adalah yang disebut dengan prestasi belajar. Menurut Kamus Besar Bahasa Indonesia (2008: 895), menyatakan bahwa "prestasi belajar adalah penguasaan pengetahuan atau ketrampilan yang dikembangkan oleh mata pelajaran, lazimnya ditunjukkan dengan nilai tes atau angka nilai yang diberikan oleh guru". Menurut Dimyati (2009: 3) menyatakan bahwa "prestasi belajar merupakan hasil dari suatu interaksi tindak belajar dan tindak mengajar. Dari sisi guru mengajar diakhiri dengan proses evaluasi hasil belajar. Dari sisi peserta didik merupakan berakhirnya puncak proses belajar". Berdasarkan pendapat ahli diatas, dapat disimpulkan bahwa prestasi belajar merupakan keseluruhan dari kegiatan dan pengalaman belajar siswa secara komprehensif dan telah melalui tahap evaluasi yang dilakukan ahlinya sebagai akhir dari dari proses belajar siswa disekolah. Prestasi merupakan adalah hasil akhirdari bukti proses belajar keberhasilanpeserta didik dalam pencapaian tujuanpengajaran dapat diketahui dan dilihat dariprestasi belajarnya pada waktu tertentu.Jadi, prestasi belajar adalah hasil yangdicapai oleh 
ISSN 2503-0752 e-ISSN: 2579-4132

siswa selama berlangsungnyaproses pembelajaran dalam jangka waktutertentu.

Dalam prestasi belajar juga terdapat faktor-faktor yang mempengaruhi prestasi belajar tersebut, adapun faktor-faktor yang mempengaruhi prestasi belajar adalah Menurut Purwanto (2014: 106) "faktor-faktor yang mempengaruhi prestasi belahar : A. Faktor internal meliputi 1). aspek fisiologis, 2). aspek psikologis, Kemudian, B. Faktor eksternal meliputi 1). aspek lingkungan. 2). aspek instrumental". Berdasarkan pendapat ahli diatas, dapat kesimpulan bahwa faktor yang dapat mempengaruhi prestasi belajar siswa dapat bersumber dari dalam dan luar diri siswa tersebut, adapun faktor dari dalam meliputi aspek fisiologis yaitu yang berhubungan dengan kesehatan rohani dan jasmani siswa dan aspek psikologis yaitu yang berhubungan dengan psikis/kejiwaan siswa, selanjutnya, faktor luar diri siswa meliputi aspek lingkungan yaitu hal yang berhubungan dengan tempat siswa melakukan interaksi sosial didalamnya dan aspek instrumental yaitu hal yang berkaitan dengan sarana dan prasarana dalam meraih prestasi belajar.

Dalam prestasi belajar, ada hal yang perlu diketahui bersama yaitu bagaimana cara mengukur prestasi belajar tersebut. Dalam kurikulum 2013 yang digunakan saat ini, prestasi belajar dapat dilihat dalam 3 ranah yaitu ranah kognitif, ranah afketif dan ranah psikomotorik. Menurut Purwanto (2014: 9) menyatakan "tiga cara untuk mengukur hasil belajar. Bidang kognitif pengukurannya menggunakan tes atau menguji siswa.Bidang sikap, pengukuran menggunakan non tes.Bidang psikomotor, pengukurannya menggunakan tes praktikum atau non tes".

\section{METODE PENELITIAN}

Penelitian ini dilaksanakan di SMA Negeri 4 Tanjungpinang pada tahun akademik 2017/2018 yang berlangusng pada bulan Agustus-September 2018.Subjek penelitian yang terlibat adalah siswa dan siswi kelas XI IPA 1 sampai XI IPA 5 yang berjumlah 84 orang.Penelitian ini merupakan penelitian kuantitatif dan termasuk ke dalam jenis penelitian korelasi atau penelitian yang mencari tingkat hubungan antara variabel bebas dan variabel terikatnya.Dalam penelitian ini terdapat dua jenis variabel yaitu variabel bebas dan variabel terikat, variabel bebasnya adalah motivasi belajar instrinsik dan variabel terikatnya adalah prestasi belajar.

Dalam penelitian ini menggunakan dua jenis teknik pengumpulan data yaitu instrument angket dan tes, instrument angket digunakan untuk mengukur nilai motivasi belajar instrinsik siswa yang terdiri dari beberapa indikator pertanyaan yang meliputi keinginan diri, kepuasaan, kebiasaan baik, kesadaran, yang berjumlah sebanyak 23 item pertanyaan, kemudian, instrument tes untuk mengukur prestasi belajar siswa, untuk soal tes yang digunakan adalah soal-soal biologi kelas X IPA yang terdiri atas materi ruang lingkup biologi, keanekaragaman hayati, virus, archaebacteria \& eubacteria, protista, jamur, tumbuhan, hewan, dan ekosistem digunakan pada siswa kelas XI IPA.

Adapun jumlah soal yang digunakan berjumlah 50 soal namun setelah dilakukan uji validitas diperoleh 42 item soal dinyatakan valid sementara 8 item soal lainnya dinyatakan tidak valid.

\begin{tabular}{|c|c|c|c|}
\hline Variabel & $\begin{array}{c}\text { Asymp-sig } \\
\text { (2 tailed) }\end{array}$ & Signifikan & Keterangan \\
\hline $\begin{array}{c}\text { Prestasi } \\
\text { belajar }\end{array}$ & 0,099 & 0,05 & Normal \\
\hline
\end{tabular}

\section{HASIL DAN PEMBAHASAN}

Secara umum penelitian ini menggunakan dua jenis uji yaitu uji prasyarat dan uji hipotesis penelitian.Uji prasyarat merupakan uji yang dilakukan sebelum dilaksanakannya penelitian agar memperoleh data penelitian yang bersifat valid dan dapat dipertanggung jawabkan yang terdiri dari uji validitas, uji realibilitas dan uji normalitas. Sementara uji hipotesis penelitian dilakukan untuk mengukur hubungan antara variabel bebas dan variabel terikat, dalam penelitian variabel bebasnya adalah motivasi belajar instrinsik dan variabel terikatnya adalah prestasi belajar Berdasarkan uji prasyarat yang telah dilakukan sebelum penelitian diperoleh beberapa hasil sebagai berikut:

Tabel 1.Tabel Hasil Uji Normalitas Motivasi Instrinsik

\begin{tabular}{|c|c|c|c|}
\hline Variabel & $\begin{array}{c}\text { Asymp- } \\
\text { sig (2 } \\
\text { tailed) }\end{array}$ & Signifikan & $\begin{array}{c}\text { Keterang } \\
\text { an }\end{array}$ \\
\hline $\begin{array}{c}\text { Motivasi } \\
\text { instrinsik }\end{array}$ & 0,084 & 0,05 & Normal \\
\hline
\end{tabular}

Berdasarkan tabel 1 diatas, dapat diambil kesimpulan bahwa nilai Asymp-sig (2 tailed) sebesar 0,084 dan hasil uji normalitas data motivasi belajar instrinsik berdistribusi normal karena nilai Asymp-sig (2 tailed) > 0,05) artinya 
persebaran data motivasi instrinsik merata dan tidak berat disalah satu sisinya.

Tabel 2. Hasil Uji Korelas Pearson Product Moment

Berdasarkan tabel 2 diatas, diperoleh data bahwa nilai Asymp-sig (2 tailed)sebesar 0,099 artinya data prestasi belajar berdistribusi normal karena nilai Asymp-sig (2 tailed) > 0,05) artinya persebaran data motivasi instrinsik merata dan tidak berat disalah satu sisinya.

Selanjutnya uji prasyarat yang dilakukan adalah uji validitas.uji validitas dilakukan untuk mengukur tingkat kevalidan instrument tes yang digunakan dalam penelitian. Uji validitas angket dilakukan oleh dosen pembimbing, sementara uji validitas instrument tes dilakukan dengan menggunakan software SPPS versi 22. Berdasarkan hasil analisis uji validitas diperoleh kesimpulan sebagai berikut: pengujian validitas menggunakan rumus korelasi person product moment melalui uji $r$ yaitu $r_{\text {hitung }}>r_{\text {tabel }}$ dengan tingkat signifikan 5\% dan dk $=\mathrm{n}-2$. Berdasarkan hasil uji validitas yang telah dilakukan diperoleh kesimpulan bahwa dari 50 item soal yang digunakan untuk mengukur prestasi belajar 42 item soal dinyatakan valid setelah dilakukan uji validitas sementara 8 item soal lainnya dinyatakan tidak valid dan tidak digunakan dalam pengumpulan data. Kemudian $r_{\text {hitung }}$ mendapatkan hasil yang lebih besar dari $r_{\text {tabel}}$, $\mathrm{r}_{\text {tabel }}$ yang didapat pada pengujian validitas sebesar 0,413.Karena setiap pertanyaan memiliki $r_{\text {hitung }}>r_{\text {tabel }}$. Dapat disimpulkan bahwa 42 item pertanyaan dapat dinyatakan sebagai alat ukur instrument tes yang baik dengan kriteria validasi soal cukup tinggi.

Kemudian uji prasyarat selanjutnya adalah uji realibilitas, uji realibilitas digunakan untuk mengukur tingkat konsisten tanggapan responden terhadap setiap item pertanyaan instrument tes, uji realibilitas dilakukan dengan metode Alpha Cronbach melalui uji $r$ yaitu $r_{\text {hitung }}$ $>r_{\text {tabel }}$ dengan taraf signifikan $5 \%$ dan dk $=\mathrm{n}-2$, yang dibantu menggunakan sistem perhitungan software SPSS 2. Berdasarkan data output hasil uji realibilitas instrument tes menunjukkan koefisien realibilitas Alpha Cronbach mendapatkan hasil

$\mathrm{r}_{\text {hitungsebesar }} \quad 0,846$ sedangkan untuk $\mathrm{r}_{\text {tabel }}$ mendapatkan hasil sebesar 0,413 dengan jumlah item pertanyaan sebanyak 42 berdasarkan lampiran 4. Sehingga dapat disimpulkan bahwa dari 42 item pertanyaan instrument test tersebut mendapatkan hasil $r_{\text {hitung }}>r_{\text {tabel. Dari hasil }}$ tersebut dapat disimpulkan bahwa realibilitas

\begin{tabular}{|ll|r|r|}
\hline & \multicolumn{1}{|c|}{$\begin{array}{c}\text { Motivasi } \\
\text { Instrinsik }\end{array}$} & \multicolumn{1}{c|}{$\begin{array}{c}\text { Prestasi } \\
\text { Belajar }\end{array}$} \\
\hline Motivasi & Pearson & 1 & $.502^{* *}$ \\
& Correlation & & .000 \\
& Sig. (2-tailed) & 84 & 84 \\
\hline Prestasi & Pearson & $.502^{* *}$ & 1 \\
Belajar & Correlation & .000 & \\
& Sig. (2-tailed) & 84 & 84 \\
& $\mathrm{~N}$ & & \\
\hline
\end{tabular}

instrumen tes masuk dalam kriteria realibitas soal yang tinggi, sehingga instrument tes tersebut dapat dikatakan sebagai instrumen yang baik digunakan dalam pengujian hipotesis.

Kemudian uji selanjutnya adalah uji hipotesis penelitian. Dalam uji hipotesis yang akan dilihat adalah tingkat hubungan antara motivasi belajar instrinsik sebagai variabel $\mathrm{x}$ terhadap prestasi belajar sebagai variabel $\mathrm{y}$. Untuk melihat hubungan antara motivasi belajar instrinsik terhadap prestasi belajar maka digunakan uji korelasi pearsonproduct moment atau uji korelasi tunggal. Berdasarkan hasil uji korelasi pearson product moment diperoleh data sebagai berikut:

Berdasarkan tabel 2 diatas, dapat disimpukan bebrapa hal yaitu: (1)Nilai Signifikasi sebesar 0,00 artinya terdapat korelasi karena nilai siginifikasi $0,00<0,05$ kemudian, (2) nilai pearson korelasi sebesar 0,50 artinya derajat hubungannya sedang karena 0,50 berada diantara $0,41-0,60$. Dapat disimpulkan bahwa uji korelasi product moment bersifat positif dengan tingkat hubungan yang sedang.

Selanjutnya, dalam pengujian hipotesis penelitian yang pertama digunakan uji korelasi product moment sebagaimana yang telah dijelaskan dalam topic sebelumnya diperoleh hasil analisis yaitu: (1)Nilai Signifikasi sebesar 0,00 artinya terdapat korelasi karena nilai siginifikasi $0,00<0,05$ kemudian, (2) nilai pearson korelasi sebesar 0,50 artinya derajat hubungannya sedang karena 0,50 berada diantara 0,41 -0,60. Berdasarkan hasil analisis di atas dapat disimpulkan bahwa untuk pengujian hipotesis yang pertama terdapat hubungan yang positif antara motivasi belajar instrinsik terhadap prestasi belajar sebesar 0,50 yang berarti korelasi sedang dan arah 
signifikasinya bersifat positif artinya setiap kenaikan motivasi instrinsik akan mengakibatkan kenaikan prestasi belajar sebesar 0,50 .

Kemudian untuk mendukung hasil analisis uji korelasi pearson product moment diatas ada beberapa teori yang dapat menguatkan teori diatas yaitu, menurut Muhibbin Syah (2008: 132) menyatakan bahwa "Faktor-faktor yang mempengaruhi prestasi belajar meliputi: (1) Faktor internal merupakan faktor atau penyebab yang berasal dari dalam diri setiap individu tersebut, seperti aspek fisiologis dan aspek psikologis. (2) Faktor eksternal, faktor eksternal dibagi menjadi 2 macam, yaitu faktor lingkungan sosial dan faktor lingkungan nonsosial".Pendapat ahli di atas mendukung hasil uji analisis di atas karena prestasi belajar dipengaruhi oleh faktor internal yang termasuk ke dalam motivasi belajar internal.

Tabel 4. Diagram Scatter Plot Hubungan Antara Motivasi Belajar Instrinsik dan Prestasi Belajar

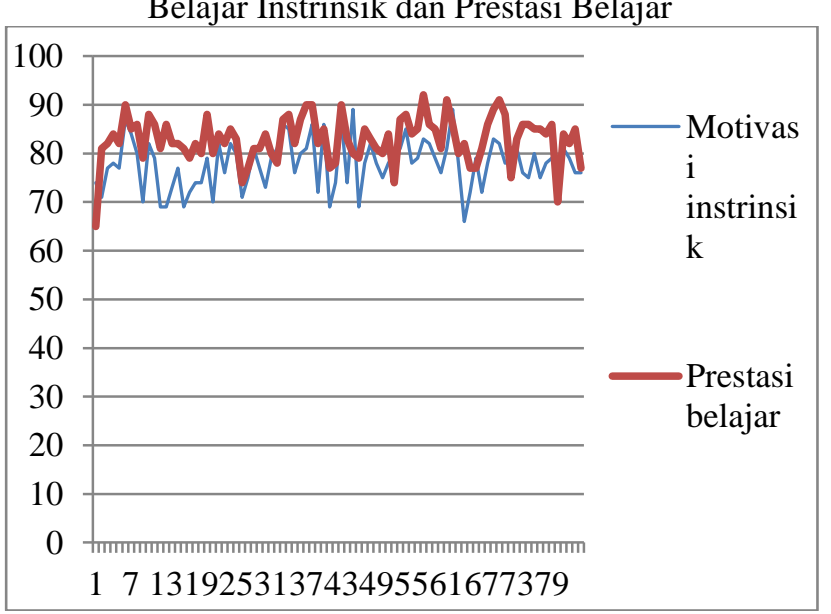

Diagram scatter plot diatas merupakan diagram yang menunjukkan tinggi dan rendanya nilai fluktuasi antara motivasi belajar instrinsik terhadap prestasi belajar per siswa yang telah melakukan pengisian instrument tes dan instrument angket pada saat penelitian.

Kemudian untuk mendukung hasil analisis uji korelasi pearson product moment diatas ada beberapa teori yang dapat menguatkan teori diatas yaitu, menurut Muhibbin Syah (2008: 132) menyatakan bahwa "Faktor-faktor yang mempengaruhi prestasi belajar meliputi: (1) Faktor internal merupakan faktor atau penyebab yang berasal dari dalam diri setiap individu tersebut, seperti aspek fisiologis dan aspek psikologis. (2) Faktor eksternal, faktor eksternal dibagi menjadi 2 macam, yaitu faktor lingkungan sosial dan faktor lingkungan
nonsosial".Berdasarkan pendapat ahli di atas dapat mendukung hasil uji analisis diatas karena prestas belajar dipengaruhi oleh faktor eksternal yang termasuk ke dalam motivasi belajar ekstrinsik.

Berdasarkan hasil analisis yang telah disampaikan diatas maka dapat diambil beberapa kesimpulan penting mengenai keberlangsungan penelitian ini diantaranya adalah, instrument yang digunakan dalam proses penelitian yaitu instrument angket dan instrument tes dinyatakan valid dan dapat digunakan dalam proses penelitian. Kemudian, uji analisis yang telah dilaksanakan juga dapat membuktikan bahwa terdapat hubungan antara motivasi belajar instrinsik terhadap prestasi belajar, dimana tingkat hubungan antara motivasi belajar instrinsik terhadap prestasi belajar sebesar 0,50 termasuk ke dalam korelasi sedang dengan arah signiffikasi yang positif artinya setiap pertambahan nilai motivasi belajar instrinsik akan meningkatkan prestasi belajar sebesar 0,50.

Maka, dapat disimpulkan bahwa motivasi belajar instrinsik sangat penting dalam setiap proses kegiatan belajar siswa di sekolah, pendapat ini didukung oleh teori ahli yang disampaikan oleh menurut Sardiman (2012: 98) berpendapat bahwa "motivasi instrinsik adalah segala hal yang berhubungan dengan dorongan yang asalnya dari dalam diri siswa sendiri yang fungsinya mendorong siswa melakukan segala macam tindakan belajar yang kaitannya erat dengan tujuan belajar". berdasarkan pendapat ahli diatas, dapat disimpulkan bahwa motivasi belajar berasal dari dalam diri siswa yang fungsinya mendorong siswa melakukan aktifitas belajar dan memiliki kaitan yang erat dengan tujuan belajar.

Selanjutnya, dalam penelitian ini peneliti akan menjelaskan nilai kebaharuan dan implikasinya bagi dunia pendidikan Indonesia. Nilai kebaharuan merupakan nilai terbarukan dalam sebuah penelitian, nilai kebaharuan menampilkan hal-hal yang baru dalam penyajian pesan penelitian ini.Sementara implikasi merupakan dampak positif yang dapat diberikan oleh penelitian tersebut bagi khalayak ramai dalam hal ini adalah dunia pendidikan Indonesia agar kedepannya pendidikan Indonesia memiliki tujuan dan arah yang jelas dapat mencerdaskan 
kehidupan bangsa Indonesia. Kedua hal diatas merupakan satu kesatuan dalam sebuah penelitian, dimana keduanya merupakan hal yang saling berkesinambungan dan tidak dapat dipisahkan satu sama lain.

Dalam penelitian ini membahas tentang tingkat hubungan antara motivasi belajar instrinsik dan prestasi belajar. adapun nilai kebaharuan dalam penelitian ini adalah peneliti merupakan penelitian yang memiliki fleksibiltas dan keterbukaan, artinya penelitian ini memiliki keterbukaan terhadap saran dan masukan dari para audience, selain itu penelitian dapat digunakan sebagai acuan bagaimana mengatasi rendahnya motivasi belajar yang rendah khususnya motivasi belajar instrinsik, memberikan pengetahuan tentang pentingnya motivasi belajar instrinsik dalam diri peserta didik.

Kemudian, implikasi yang dapat diberikan oleh penelitian ini adalah peneliti merumuskan beberapa strategi dalam proses pembelajaran yang dapat digunakan untuk meningkatkan motivasi belajar instrinsik guna meningkatkan prestasi belajar siswa. Adapun strategi yang dimaksud adalah sebagai berikut:

1. Memberikan penghargaan dengan menggunakan kata-kata, seperti ucapan bagus sekali, hebat, dan menakjubkan. Penghargaan yang dilakukan dengan kata-kata ini mengandung makna yang positif karena menimbulkan interaksi dan pengalaman pribadi bagi siswa itu sendiri.

2. Memberikan nilai ulangan sebagai pemacu siswa untuk belajar lebih giat. Dengan mengetahui dalam belajar maka siswa akan termotivasi untuk belajar lebih giat lagi.

3. Mengadakan permainan dan menggunakan stimulus. Mengemas pembelajaran dengan menciptakan suasana yang menarik sehingga proses pembelajaran menjadi menyenangkan dan dapat melibatkan afektif dan psikomotorik siswa. Proses pembelajaran yang menarik akan

memudahkan siswa memahami dan mengingat apa yang disampaian.

\section{KESIMPULAN DAN SARAN}

\section{Kesimpulan}

Berdasarkan hasil penelitian dapat disimpulkan bahwa penelitian merupakan penelitian korelasi dengan pendekatan kuantitaif.Penelitian ini dilaksanakan untuk mengukur tingkat hubungan antara motivasi belajar instrinsik terhadap prestasi belajar siswa kelas XI IPA di SMA Negeri 4 Tanjungpinang. Berdasarkan uji prasyarat yang telah dilaksanakan dapat diambil kesimpulan bahwa uji normalitas pada data motivasi belajar instrinsik dan prestasi belajar berdistribusi normal, kemudian berdasarkan uji validitas, instrument yang digunakan tekah dinyatakan valid dan dapat digunakan dalam penelitian sekanjutnya, berdasarkan uji realibilitas maka data dapat dipertanggung jawabkan dan memiliki tingkat reali yang tinggi sehingga dapat digunakan.

Kemudian berdasarkan hasil uji hipotesis penelitian untuk melihat tingkat hubungan antara motivasi belajar instrinsik terhadap prestasi belajar diperoleh nilai korelasi sebesar 0,50 yang termasuk ke dalam korelasi sedang dengan arah signifikasi yang positif artinya setiap pertambahan nilai motivasi belajar instrinsik akan meningkatkan prestasi belajar sebesar 0,50.

\section{Saran}

Hubungan antara motivasi belajar instrinsik terhadap prestasi belajar lebih lanjut perlu memerhatikan beberapa saran yaitu:

Untuk mempertahankan prestasi belajar siswa yang baik dan konsisten salah satunya melalui peningkatan aspek-aspek yang

\section{DAFTAR PUSTAKA}

Dimyati. 2009. Pembelajaran Terpadu Untuk Taman Kanak-kanak/ Raudatul Athfal dan Sekolah Dasar. Kencana, Jakarta

Muhibin Syah. 2008. Psikologi Pendidikan dengan Pendekatan Baru. Rosdakarya, Bandung.

Ngalim, Purwanto. 2014. Evaluasi Hasil belajar.Pustaka Pelajar, Yogyakarta Sardiman. 2010. Interaksi dan Motivasi Belajar Mengajar. RajaGrafindo Persada, Jakarta.

Sardiman. 2012. Interaksi dan Motivasi Belajar Mengajar. RajaGrafindo Persada, Jakarta 
J. Pedagogi Hayati Vol. 3 No. 1

CProgram Studi pendidikan Biologi

FKIP Universitas Maritim Raja Ali Haji

ISSN 2503-0752 e-ISSN: 2579-4132

Supandi. 2011. Menyiapkan Kesuksesan Anak Anda.

PT Gramedia Pustaka Utama, Jakarta

Thomas, Kristo M. 2010. Andalah Para Orang Tua Motivator Terbaik Bagi Remaja. PT. Alex Media Komputindo: Jakarta. 